\title{
Ocena jakości życia i zadowolenia ze zdrowia pacjentów z nadciśnieniem tętniczym
}

\author{
Assessment of the quality of life and health satisfaction of \\ patients with hypertension
}

\author{
MARIA KLARKOWSKA ${ }^{1}$, ANNA ANTCZAK ${ }^{2,3}$ \\ ${ }^{1}$ NZOZ Centrum Medyczne „NAD BRDĄ” w Bydgoszczy \\ 2 Zakład Pielęgniarstwa Neurologicznego i Neurochirurgicznego, Collegium Medicum \\ w Bydgoszczy, Uniwersytet Mikołaja Kopernika w Toruniu, \\ ${ }^{3}$ Instytut Nauk o Zdrowiu, Państwowa Wyższa Szkoła Zawodowa we Włocławku
}

DOI: http://dx.doi.org/10.21784/IwP.2017.003

ISSN: 2451-1846

\section{Streszczenie:}

Wstęp. W aspekcie nauk medycznych definicje jakości życia sprowadzają się głównie na korelacji zdrowie-choroba, jednak mimo dużego zainteresowania tą kategorią, nie udało się wypracować uniwersalnej definicji, przyjmowanej przez całe środowisko medyczne. Nadciśnienie tętnicze to choroba cywilizacyjna, która szczególnie dotyka mieszkańców krajów wysoko rozwiniętych. Wyniki badań epidemiologicznych jednoznacznie wskazują, że nadciśnienie tętnicze jest jednym $\mathrm{z}$ najważniejszych czynników ryzyka wystąpienia chorób układu sercowo-naczyniowego. Czynniki ryzyka postępu nadciśnienia tętniczego to zarówno czynniki modyfikowalne, takie jak styl życia pacjenta, czynniki środowiskowe, a także czynniki nie modyfikowalne, jak cechy jednostki wrodzone, które stanowią ryzyko podatności na pewne choroby lub zaburzenia w stanie zdrowia. Dla celów analizy założono, że płeć, wiek chorego, miejsca zamieszkania, czas trwania choroby oraz wskaźnik BMI mogą wykazywać istotną korelację z subiektywną oceną jakości życia. 
Cel. Celem pracy jest zbadanie oceny jakości życia pacjentów na nadciśnienie tętnicze w środowisku oraz ich zadowolenia ze stanu swojego zdrowia, analizując wybrane czynniki ryzyka.

Materiał i metody. Badaniem objęto 100 pacjentów Zakładu Opieki Zdrowotnej Centrum Medyczne „Nad Brdą” w Bydgoszczy, ze zdiagnozowanym nadciśnieniem tętniczym. Pomiaru jakości życia pacjentów dokonano przy użyciu polskiej wersji kwestionariusza WHOQOL-BREF. Natomiast w celu poznania czynników socjo-demograficznych chorych do badania włączono ankietę własną. Analizę statystyczną przeprowadzono przy użyciu programu Statistica 10.0. Przyjęto poziom istotności $p \leq 0,05$.

Wyniki. Największa grupa ankietowanych oceniła jakość swojego życia pozytywnie - $64,0 \%$ (ocena dobra i bardzo dobra), najmniej negatywnie $4,0 \%$. Zadowolenie ze zdrowia, najwięcej badanych oceniło przeciętnie $48,0 \%$, natomiast najmniej negatywnie $-13,0 \%$. Nieznacznie wyższą ocenę jakości życia (ze względu na mniejsze odchylenie standardowe) odnotowano $\mathrm{w}$ grupie kobiet. $\mathrm{W}$ aspekcie oceny wpływu wieku respondentów na jakość życia, najwyższe oceny zaobserwowano w wieku 51-60 lat oraz 41-50 lat, a najniższe $\mathrm{w}$ wieku do 40 lat. Zadowolenie ze zdrowia najwyżej ocenili ankietowani w wieku do 40 lat oraz 51-60 lat, najniżej w wieku powyżej 60 lat. Nie odnotowano istotnych statystycznie różnic pomiędzy mieszkańcami wsi i miasta, dotyczących zarówno jakości życia jak i zadowolenia ze zdrowia. Czas chorowania na nadciśnienie tętnicze, nie pozostawał $\mathrm{w}$ istotnej statystycznie korelacji z wynikami zarówno jakości życia jak i zadowolenia ze zdrowia ( $>00,05)$, we wszystkich ocenianych grupach wynik był pozytywny. Natomiast wskaźnik BMI pozostawał $\mathrm{w}$ istotnej statystycznie, niskiej korelacji z wynikami zadowolenia ze zdrowia $(\mathrm{p}<0,05)$.

Wnioski. 1. Pacjenci z nadciśnieniem tętniczym oceniają jakość swojego życia jako dobrą. Natomiast stan zdrowia oceniają jako przeciętny. 2. Nie stwierdzono różnicy w jakości życia pacjentów z nadciśnieniem tętniczym ze względu na płeć. 3. Respondenci powyżej 60 . roku życia wskazują na niższe zadowolenie ze zdrowia oraz jakości życia niż inne grupy wiekowe. 4. Mieszkańcy miasta i wsi nie wykazują istotnej różnicy w zakresie oceny jakości życia. 5. Osoby chorujące na nadciśnienie tętnicze powyżej 20 lat słabiej niż inne grupy oceniają jakość życia. 6. Pacjenci z nadciśnieniem tętniczym wykazują tendencję do występowania nadwagi. Pacjenci z nadwagą oraz otyłością niżej oceniają jakość życia od osób z prawidłowym BMI. 
Słowa kluczowe: nadciśnienie tętnicze, jakość życia, zadowolenie ze zdrowia

\begin{abstract}
:
Introduction. As far as medical sciences are concerned, the definitions of the quality of life are mainly related to the correlation between health and the disease, but despite the great interest in this category, the universal definition adopted by the whole medical community has failed. Hypertension is a civilization disease which affects in particular residents of highly developed countries. Epidemiological findings clearly indicate that hypertension is one of the most important risk factors for cardiovascular disease. Risk factors for the progression of hypertension include both modifiable factors such as the patient's life style, environmental factors, as well as non-modifiable ones such as innate features that present a risk of susceptibility to certain diseases or disorders in health. For the purposes of the analysis, it was assumed that the gender, age of the patient, place of residence, duration of illness and BMI index may have a significant correlation with the subjective quality of life assessment.
\end{abstract}

Aim. The aim of the study is to evaluate the quality of life of patients with hypertension in the environment and their satisfaction with their health condition by analyzing selected risk factors.

Material and methods. The study included 100 patients of the Medical Center "Nad Brdą" in Bydgoszcz, diagnosed with hypertension. The quality of life was measure dusing the Polish version of the WHOQOL-BREF questionnaire. Whereas in order to know the socio-demographic factors of the patients, our own questionnaire was included. Statistical analysis was performed by means of Statistica 10.0. The significance level $p \leq 0.05$ has been adopted.

Results. The largest group of respondents assessed the quality of their lives positively - $64.0 \%$ (good and very good), the least negative - $4.0 \%$. Satisfaction with health, the majority of respondents assessed as average $48.0 \%$, whereas the least negative $-13.0 \%$. A slightly higher quality of life assessment (due to lower standard deviation) was observed in the group of women. As regards the impact of respondents' age on the quality of life, the highest scores were observed in the agegroupsranging51-60 years and 41- 
50 years, and the lowest in the age group under 40 years. Satisfaction with health was highest among respondents aged 40 and 51-60 years, the lowest in the age group over 60 years. There were no statistically significant differences observed between rural and urban residents regarding both the quality of life and satisfaction with health. The duration of suffering from hypertension was not in statistically significant correlation with both the quality of life and satisfaction with health $(p>0.05)$ in all groups surveyed the result was positive. The BMI index however, was in statistically significant, low correlation with life satisfaction results $(\mathrm{p}<0.05)$.

Conclusions. 1. Patients with hypertension assess the quality of their lives as good. Where as their health condition is assessed as average. 2. There was no difference observed in the quality of life of patients with hypertension according to gender. 3. Respondents over the age of 60 indicate lower satisfaction with health and the quality of life than other age groups. 4. City and village residents do not show any significant difference in the quality of life assessment. 5. Patients with hypertension lasting over 20 years evaluate the quality of life lower than other age groups. 6 . Patients with hypertension tend to be overweight. Over weight patients and those with obesity assess the quality of life lower than the respondents with correct BMI.

Keywords: hypertension, quality of life, satisfaction with health

\section{Wstęp}

Jakość życia w aspekcie badawczym i naukowym zyskuje w ostatnich latach coraz większe zainteresowanie. Opiera się ono na całościowym, a jednocześnie zindywidualizowanym podejściu do pacjenta. Badacze jako cel nadrzędny stawiają sobie poznanie subiektywnych odczuć pacjenta, wpływu choroby na jego dobrostan, jak również krytyczna ocena stosowanej terapii. Obecnie, we współczesnej medycynie uważa się, że uzyskanie informacji od jednostki najbardziej zainteresowanej przebiegiem leczenia i najlepiej odczuwającym jego skutki - czyli pacjenta, pozwoli uzyskać optymalny dla danej sytuacji zdrowotnej program terapii. Jakość życia staje się pojęciem wielowymiarowym i interdyscyplinarnym, mimo to nie wypracowano dotychczas jednoznacznej definicji jakości życia, a różne dziedziny nauk, a nawet różni autorzy w obrębie jednej 
dyscypliny inaczej opisują to pojęcie. Istnieje więc wiele definicji oraz różnych metod próbujących zmierzyć tę trudną do uchwycenia wartość.

Rozważając aspekt medyczny jakość życia definiuje się w korelacji zdrowie-choroba, jednak mimo dużego zainteresowania tą kategorią, nie udało się wypracować uniwersalnej definicji, przyjmowanej przez całe środowisko medyczne. W 1994 roku Światowa Organizacja Zdrowia po raz pierwszy zdefiniowała jakość życia jako postrzeganie przez człowieka jego życiowej sytuacji, w zależności od oczekiwań i celów. Według koncepcji WHO jakość życia obejmuje funkcjonowanie $\mathrm{w}$ podstawowych sferach życia fizycznej, psychicznej, społecznej oraz samooceny zdrowia. WHO wskazuje, że jakość życia to nie tylko subiektywna ocena danej jednostki w kontekście oczekiwań i standardów kulturowych i społecznych, ale także ogólny stan zdrowia fizycznego, rozwój emocjonalny oraz możliwość samoopieki i samorealizacji [1].

Nadciśnienie tętnicze to choroba cywilizacyjna, która szczególnie dotyka mieszkańców krajów wysoko rozwiniętych. Według wyników badań epidemiologicznych jednoznacznie nadciśnienie tętnicze jest jednym $\mathrm{z}$ najważniejszych czynników ryzyka wystąpienia chorób układu sercowo-naczyniowego. Stanowią one jedną $\mathrm{z}$ głównych przyczyn zgonów, chorobowości i niepełnosprawności w całej Europie oraz w Stanach Zjednoczonych. Według danych Światowej Organizacji Zdrowia na świecie na nadciśnienie tętnicze choruje prawie miliard osób, a w danych szacunkowych wskazuje się, że w 2025 roku liczba ta przekroczy 1,5 miliarda [2].

Nadciśnieniem tętniczym nazywany jest zespół objawów klinicznych towarzyszący podwyższonemu ciśnieniu krwi powyżej normy ustalonej według wieku i płci. Za nadciśnienie uznaje się stan, gdy nieprawidłowość dotyczy tylko ciśnienia skurczowego lub tylko rozkurczowego, bądź też obydwu równocześnie [3]. W przypadku znacznej większości pacjentów, bo u ponad 90\%, nadciśnienie 
tętnicze ma charakter pierwotny. Zaburzenie regulacji ciśnienia krwi jest uwarunkowane przez wiele czynników, a jego rozwojowi sprzyjają zarówno czynniki niemodyfikowalne, jak i czynniki modyfikowalne. $\mathrm{Z}$ reguły ujawnia się dopiero po 30. roku życia, częściej u kobiet, u których charakteryzuje się mniejszą skłonnością do powikłań narządowych. Przez pierwsze lata jego przebieg jest bezobjawowy, rozwija się bez żadnych dolegliwości, przyspieszając jednak zmiany miażdżycowe w naczyniach wieńcowych i kilkakrotnie zwiększając ryzyko zawału mięśnia serca [4].

Czynniki ryzyka postępu nadciśnienia tętniczego to zarówno styl życia pacjenta, czynniki środowiskowe, a także czynniki genetyczne, które stanowią ryzyko podatności na pewne choroby lub zaburzenia w stanie zdrowia. Istnieje duży zakres czynników ryzyka, na które pacjent nie ma wpływu, jak i te które może modyfikować poprzez zmianę stylu życia [5].

Obserwując badania epidemiologiczne nadciśnienie tętnicze to choroba, która dotyka w Polsce około jedną trzecią społeczeństwa, a także jest jednym z największych czynników ryzyka powikłań sercowo-naczyniowych [6]. Z racji tego, iż problem ten dotyka tak dużej części populacji, istotna wydaje się ocena dobrostanu pacjentów dotkniętych tym schorzeniem.

Celem pracy jest zbadanie oceny jakości życia pacjentów z nadciśnieniem tętniczym oraz ich zadowolenie ze stanu swojego zdrowia.

Dla celów analizy założono, że płeć, wiek chorego, miejsca zamieszkania, czas trwania choroby oraz wskaźnik BMI mogą wykazywać istotną korelację z subiektywną oceną jakości życia.

\section{Materiał i metody}

Badaniem objęto 100 pacjentów Zakładu Opieki Zdrowotnej Centrum Medyczne „Nad Brdą” w Bydgoszczy, ze zdiagnozowanym nadciśnieniem tętniczym. Ponad połowę badanych pacjentów stanowiły kobiety - 64\%, co trzeci badany był mężczyzną. Do badania rekrutowani byli pacjenci niezależnie od wieku. Średnia wieku 
badanych wyniosła 59 lat. Najliczniejszą grupę stanowili badani w wieku powyżej 60 roku życia - 40\% oraz w wieku 51-60 lat - 35\%. Najmniej liczną grupą były osoby $w$ wieku do 30 lat - 2\%. Zdecydowana większość pacjentów zamieszkuje w mieście - 76\%. Zaledwie co piąty badany to mieszkaniec wsi. Badaną próbę przeanalizowano pod kątem czasu występowania nadciśnienia tętniczego. Najwięcej badanych wskazało, że choruje na nadciśnienie tętnicze poniżej 5 lat - 37,0\%, najmniej powyżej 20 lat - 18,0\%. Najliczniejszą grupę stanowią badani $\mathrm{z}$ nadwagą - 40,0\% oraz wartością prawidłową - 27,0\%. Wśród respondentów można również wyróżnić stosunkowo liczną grupę z I stopniem otyłości - 20,0\%. Natomiast najmniej licznym zbiorem są chorzy z III stopniem otyłości - 3,0\%. Do celów dalszej analizy ze względu na liczebność, badani z III stopniem otyłości, zakwalifikowani zostaną do grupy z II stopniem otyłości. Średni wskaźnik BMI badanych wyniósł 28,42. To wskaźnik nadwagi. Odchylenie standardowe stanowiło ponad 18,9\% wartości średniej, co świadczy o przeciętnym zróżnicowaniu BMI.

Pomiaru jakości życia pacjentów dokonano przy użyciu polskiej wersji kwestionariusza WHOQOL-BREF. Natomiast w celu poznania czynników socjo-demograficznych chorych do badania włączono ankietę własną. Analizę statystyczną przeprowadzono przy użyciu programu Statistica 10.0. Przyjęto poziom istotności $p \leq 0,05$.

\section{Wyniki}

Przedstawione wyniki opracowano na podstawie badań własnych i dokonano korelacji w zależności od badanych czynników socjodemograficznych.

Tabela 1. Jakość życia i zadowolenie ze zdrowia $w$ opinii badanych.

\begin{tabular}{|l|c|c|c|c|}
\hline \multirow{2}{*}{ ocena skali } & \multicolumn{2}{|c|}{ jakość życia } & \multicolumn{2}{c|}{$\begin{array}{c}\text { zadowolenie } \\
\text { ze zdrowia }\end{array}$} \\
\cline { 2 - 5 } & liczba & $\%$ & liczba & $\%$ \\
\hline
\end{tabular}




\begin{tabular}{|c|c|c|c|c|}
\hline bardzo zła (1 pkt.) & 2 & 2,0 & 3 & 3,0 \\
\hline zła (2 pkt.) & 2 & 2,0 & 10 & 10,0 \\
\hline ani dobra ani zła (3 pkt.) & 32 & 32,0 & 48 & 48,0 \\
\hline dobra (4 pkt.) & 55 & 55,0 & 36 & 36,0 \\
\hline bardzo dobra (5 pkt.) & 9 & 9,0 & 3 & 3,0 \\
\hline razem & 100 & 100,0 & 100 & 100,0 \\
\hline
\end{tabular}

Źródło: wynik badań własnych

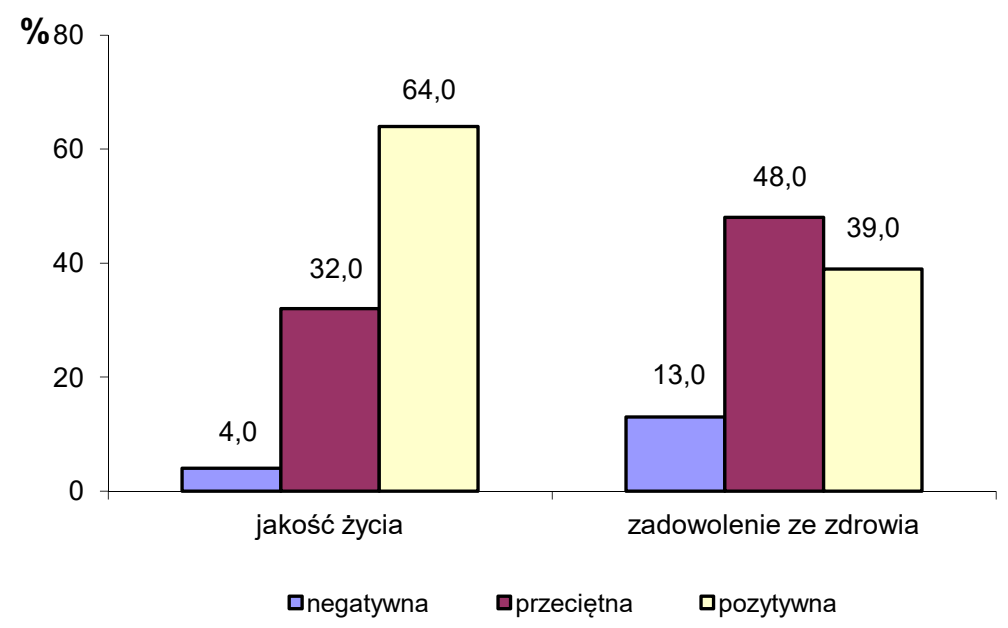

Rycina1. Rozkład oceny jakości życia i zadowolenia ze zdrowia badanych.

Źródło: wynik badań własnych

Najwięcej badanych uznało, że jakość ich życia jest dobra - 55,0\% lub ani dobra ani zła - 32,0\%. Natomiast najmniej wskazało, że zła lub bardzo zła - po 2,0\%. Oceniając zdrowie, najwięcej badanych wskazało na ocenę ani dobra ani zła - 48,0\% lub dobra - 36,0\%. Najmniej wskazało na ocenę bardzo złą i bardzo dobrą - po 3,0\%. 
Średnia ocena jakości życia wyniosła - 3,67 punktu - to wynik pozytywny. Zadowolenie ze zdrowia oceniono niżej - średnia 3,26 punktu - to wynik przeciętny.

Podsumowując, największa grupa ankietowanych oceniła jakość swojego życia pozytywnie - 64,0\% (ocena dobra i bardzo dobra), najmniej negatywnie - 4,0\%. Zadowolenie ze zdrowia, najwięcej badanych oceniło przeciętnie $-48,0 \%$, natomiast najmniej negatywnie $-13,0 \%$.

Ze względu na poziom istotności $(\mathrm{p}>0,05)$, nie odnotowano istotnych statystycznie różnic pomiędzy kobietami i mężczyznami, dotyczących zarówno jakości życia jak i zadowolenia ze zdrowia.

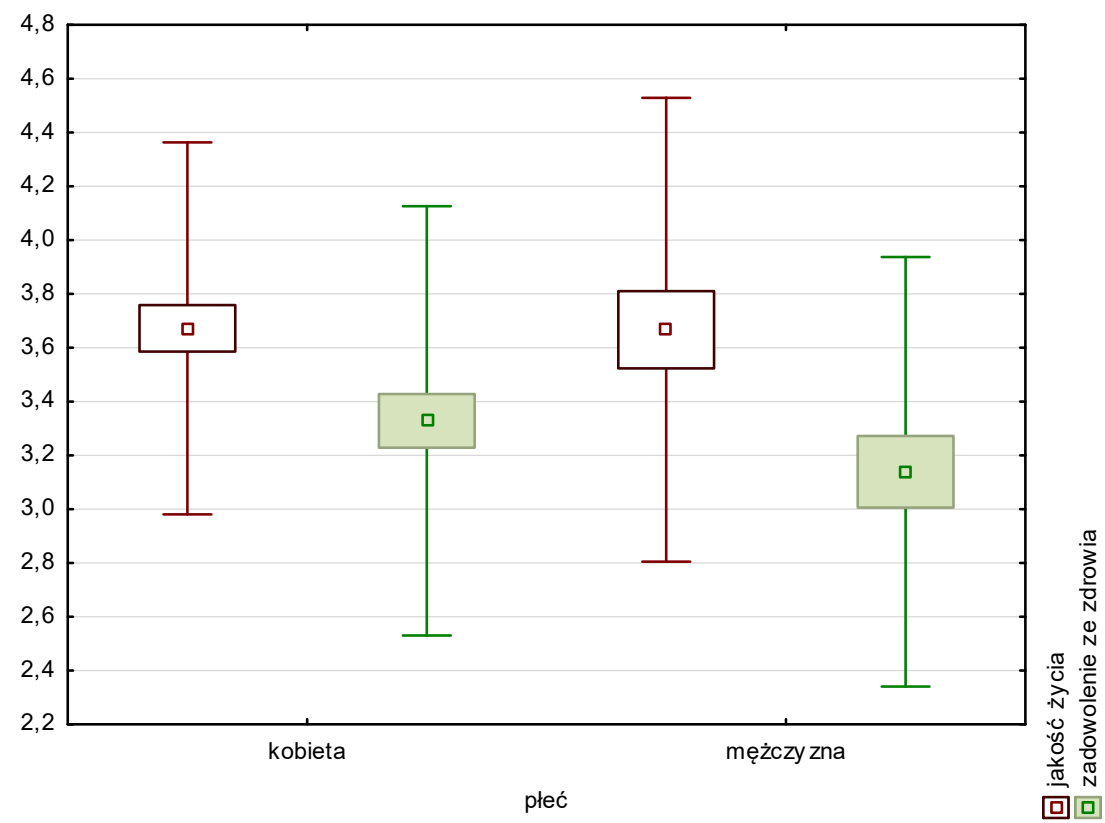

Rycina 2. Rozkład wyników oceny jakości życia badanych w grupach płci.

Źródło: wynik badań własnych 
Nieznacznie wyższą ocenę jakości życia (ze względu na mniejsze odchylenie standardowe) odnotowano $w$ grupie kobiet. Podobnie w przypadku oceny zadowolenia ze zdrowia, gdzie kobiety uzyskały nieco wyższy wynik. Wynik jakości życia w obu grupach pozytywny, zadowolenia ze zdrowia przeciętny.

Grupy wiekowe nie pozostawały w istotnej statystycznie korelacji z wynikami zarówno jakości życia jak i zadowolenia ze zdrowia $(p>0,05)$.

W aspekcie oceny wpływu wieku respondentów na jakość życia, najwyższe oceny zaobserwowano w wieku 51-60 lat oraz 41-50 lat, a najniższe $\mathrm{w}$ wieku do 40 lat. Wynik wyniki wszystkich grup wiekowych pozytywne. Zadowolenie ze zdrowia najwyżej ocenili ankietowani w wieku do 40 lat oraz 51-60 lat, najniżej w wieku powyżej 60 lat. We wszystkich grupach wyniki przeciętne z wyjątkiem grupy do 40 lat - pozytywny na granicy przeciętnego.

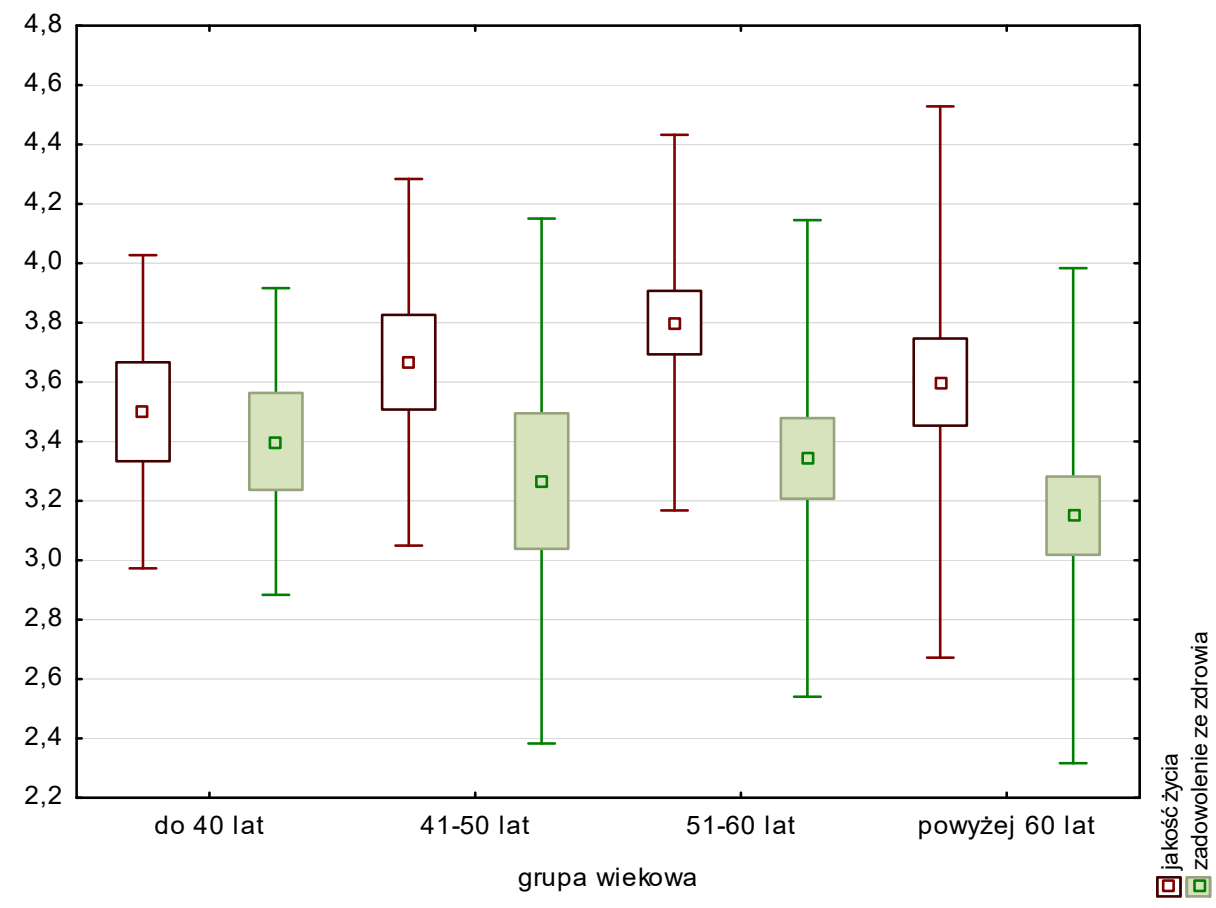


Rycina 3. Rozkład wyników średnich oceny jakości życia badanych w grupach wiekowych.

Źródło: wynik badań własnych

Odpowiedzi dotyczące jakości życia oraz zadowolenia ze zdrowia odniesiono również do miejsca zamieszkania badanych. Jednakże względu na poziom istotności ( $p>0,05)$, nie odnotowano istotnych statystycznie różnic pomiędzy mieszkańcami wsi i miasta, dotyczących zarówno jakości życia jak i zadowolenia ze zdrowia.

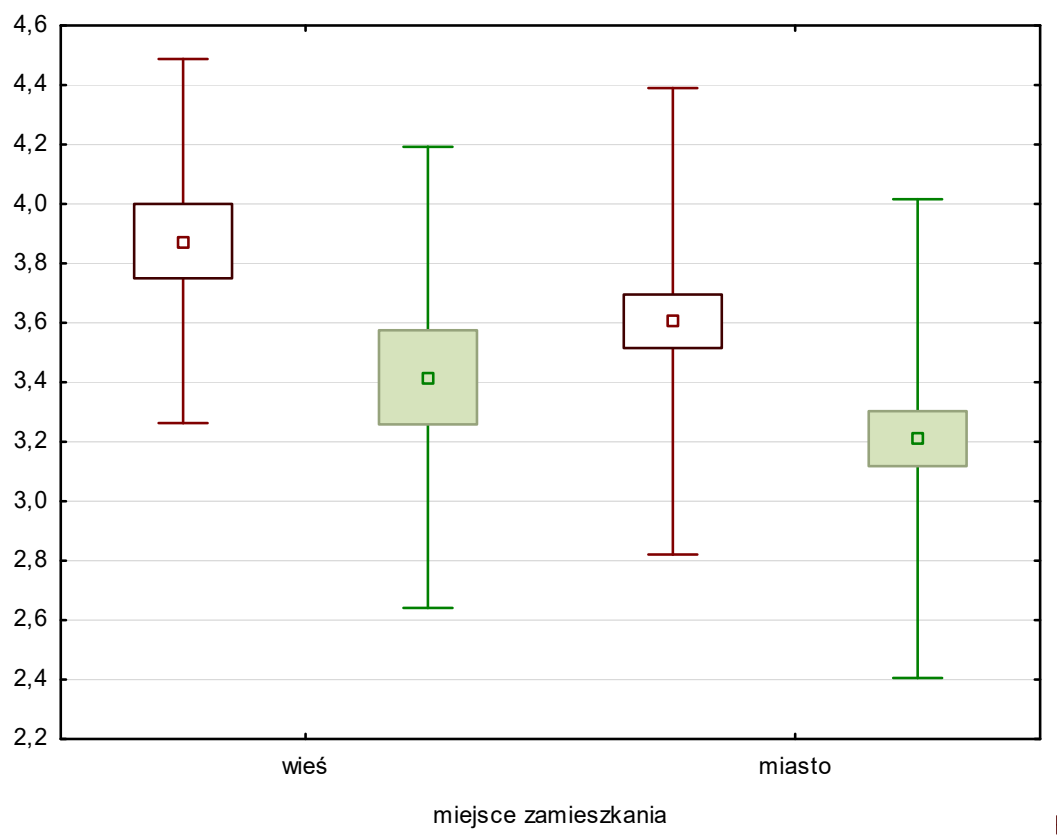

Rycina 4. Rozkład wyników oceny jakości życia badanych w grupach miejsca zamieszkania.

Źródło: wynik badań własnych

Nieznacznie wyższą zarówno jakość życia oraz zadowolenie ze zdrowia prezentowali mieszkańcy wsi. Wszystkie wyniki pozytywne 
z wyjątkiem zadowolenie ze zdrowia w grupie mieszkańców miasta przeciętne.

Czas chorowania na nadciśnienie tętnicze nie pozostawał w istotnej statystycznie korelacji z wynikami zarówno jakości życia, jak i zadowolenia ze zdrowia ( $p>0,05)$. Wynik zadowolenia ze zdrowia był na granicy istotności.

Najwyżej jakość życia ocenili badani chorujący 11-20 lat oraz poniżej 5 lat (mniejsze odchylenie standardowe) i 5-10 lat. We wszystkich grupach wynik pozytywny. Najniżej jakość życia oceniły osoby chorujący powyżej 20 lat - wynik przeciętny. Zadowolenie ze zdrowia najwyżej ocenili badani chorujący poniżej 5 lat (mniejsze odchylenie standardowe) i 5-10 lat. Najniższej oceny dokonywali osoby chorujące powyżej 20 lat. We wszystkich grupach wyniki przeciętne. 


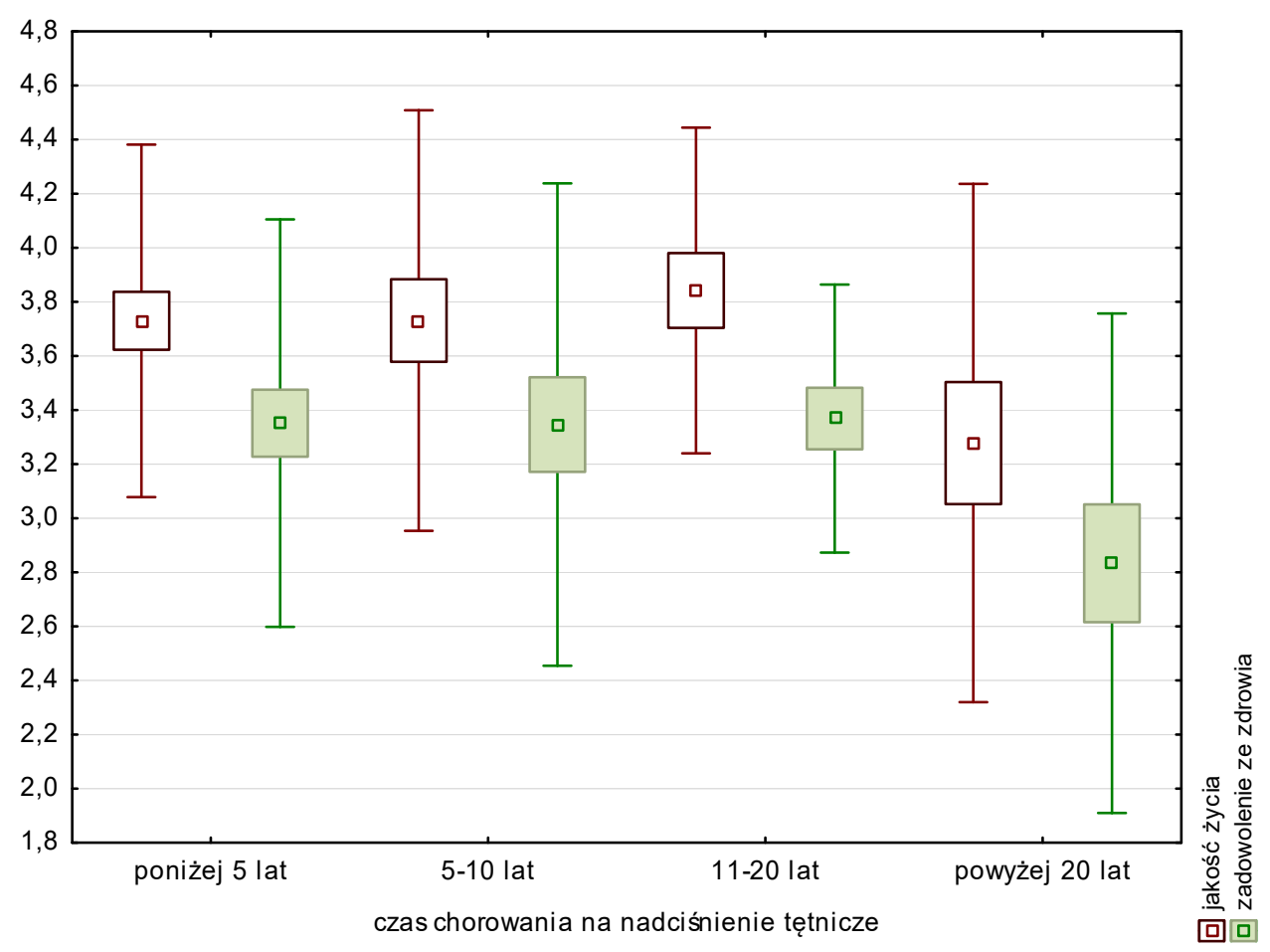

Rycina 5. Rozkład wyników średnich oceny jakości życia badanych ze względu na czas chorowania.

Źródło: wynik badań własnych

Wskaźnik BMI pozostawał w istotnej statystycznie, niskiej korelacji z wynikami zadowolenia ze zdrowia $(p<0,05)$. Najwyżej jakość życia ocenili badani z wartością prawidłową oraz II stopniem otyłości. Najniżej badani z I stopniem otyłości. We wszystkich grupach wynik pozytywny. Zadowolenie ze zdrowia najwyżej ocenili badani z wartością prawidłową BMI oraz $\mathrm{z}$ nadwagą (mniejsze odchylenie standardowe). Najniżej z kolei respondenci z II stopniem otyłości. Wynik w grupie wartości prawidłowej BMI pozytywny, w pozostałych grupach przeciętny. 


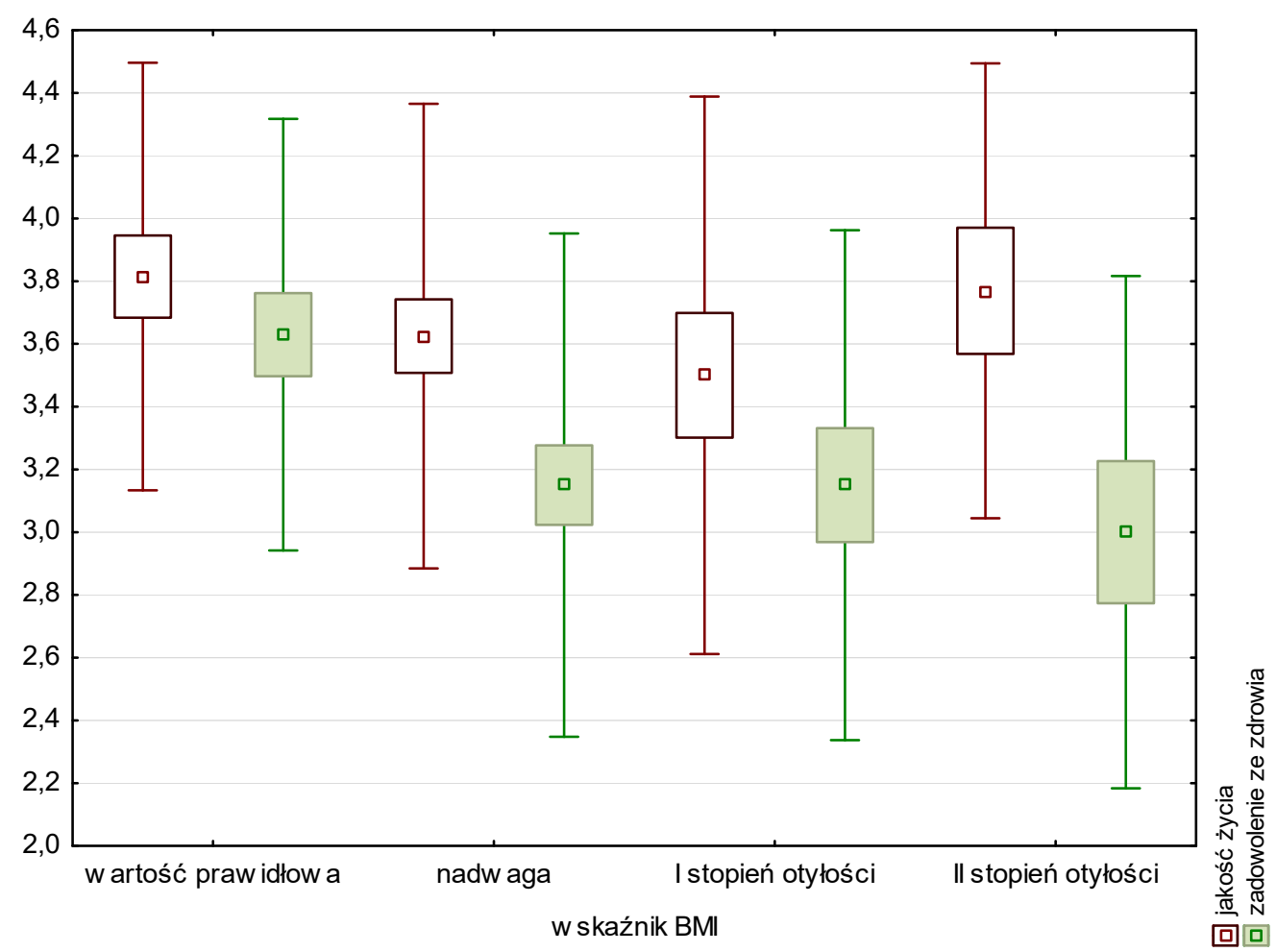

Rycina 6. Rozkład wyników średnich oceny jakości życia badanych w grupach wskaźnika BMI.

Źródło: wynik badań własnych

\section{Dyskusja}

Współczesna medycyna nie tylko maksymalizuje starania na rzecz wydłużenia trwania życia, ale również przywrócenia jego stanu sprzed choroby. Tak więc badania nad jakością życia mają obecnie doniosłe znaczenie, pozwalają bowiem uchwycić subiektywne odczucia pacjenta dotyczące nie tylko stanu zdrowia, ale również innych aspektów życia. W 1994 r. WHO określiła, iż jakość życia obejmuje funkcjonowanie człowieka w czterech obszarach: fizycznym, psychicznym, społecznym oraz samooceny zdrowia [7]. Problem ten 
należy więc widzieć $\mathrm{w}$ szerszej perspektywie, biorąc pod uwagę możliwości pacjenta $\mathrm{w}$ zakresie samorealizacji i samoopieki, patrząc na chorego w sposób holistyczny, zarówno od strony samopoczucia fizycznego oraz psychicznego, jak i sfery społecznej, duchowej i socjalnej. W tym kontekście w obszar dociekań nad jakością życia doskonale wpisuje się skala WHOQOL-BREF, która umożliwia badanie pacjentów pod kątem czterech dziedzin życia: fizycznej, psychologicznej, relacji społecznych i środowiska.

Z badań nad jakością życia wynika, iż jest to problem złożony, składający się $\mathrm{z}$ wielu aspektów. Tak więc $\mathrm{w}$ trakcie procesu badawczego należy mieć na uwadze wiele współistniejących ze sobą czynników $[8,9,1]$.

Badacze zajmujący się wpływem starzenia się na jakość życia podkreślają, iż jest to problem złożony, uwarunkowany w znacznym stopniu warunkami genetycznymi, stylem życia i dostępem do opieki medycznej, na co z kolei wpływ mają uwarunkowania społecznoekonomiczne [10]. Badania nad jakością życia osób starszych wykazały, iż ulega ona znacznemu obniżeniu w podeszłym wieku [11]. Wyniki analiz M. Muszalik jednoznacznie wskazują, iż wraz z wiekiem narastają dolegliwości bólowe, spada energia życiowa, a także nasilają się problemy ze snem i poczucie społecznego wyobcowania [12].

Mając na uwadze doniesienia wielu autorów postawiono hipotezę, iż subiektywna ocena jakości życia obniża się wraz z wiekiem. Została ona potwierdzona tylko częściowo, bowiem o ile w dziedzinach fizycznej i socjalnej można zauważyć wyraźny spadek zadowolenia skorelowany $\mathrm{z}$ wiekiem, to dziedzinę psychologiczną najlepiej ocenili badani w wieku 51 - 60 lat. Natomiast dziedzina środowiskowa uzyskała najlepsze wyniki w grupie 41 - 50 lat. Osoby najmłodsze, w wieku do 40 lat, plasują się zazwyczaj na drugim miejscu pod względem oceny jakości życia. Najmniejsze zadowolenie, we wszystkich aspektach życia prezentują chorzy po 60. roku życia. Może być to związane nie tylko z pogarszającym się stanem zdrowia, 
ale również z zaprzestaniem aktywności zawodowej, a co za tym idzie pogorszeniem sytuacji ekonomicznej.

Badania własne potwierdziły natomiast hipoteze o negatywnym wpływie zarówno występowania innych schorzeń jak i długości czasu trwania choroby nadciśnieniowej na jakość życia. Osoby chorujące na nadciśnienie od ponad 20 lat najniżej wśród badanej populacji oceniają jakość życia we wszystkich badanych dziedzinach. Pacjenci cierpiący również na inne schorzenia ocenili niżej jakość życia w każdej z badanych sfer, jednak szczególnie widoczne różnice można zauważyć $\mathrm{w}$ dziedzinie fizycznej oraz psychologicznej.

Wyniki te zbieżne są $\mathrm{z}$ doniesieniami innych autorów. Jak wynika $\mathrm{z}$ badań Stachowskiej $\mathrm{i}$ in. czas trwania choroby jest czynnikiem silnie różnicującym jakość życia, a obniżeniu ulega szczególnie jakość w wymiarze zdrowia psychicznego [13]. Natomiast inni badacze zwracają uwagę, iż jakość życia u chorych na nadciśnienie jest silnie skorelowana z występowaniem innych chorób oraz powikłań nadciśnienia $[14,15]$. Stąd też tak bardzo istotne wydaje się być wczesne wykrywanie i zapobieganie chorobom wywołanym przez nadciśnienie, jak zawał mięśnia sercowego czy udar mózgu.

Z doniesień wynika, iż nadwaga i otyłość sprzyjają rozwojowi nadciśnienia tętniczego [16]. BMI pacjenta ma ścisły związek z wysokością ciśnienia tętniczego, a największym czynnikiem ryzyka jest tzw. otyłość brzuszna. W zaleceniach Polskiego Towarzystwa Nadciśnienia Tętniczego czytamy, że obwód pasa przekraczający 88 cm u kobiet i $102 \mathrm{~cm}$ u mężczyzn stanowi samodzielny czynnik ryzyka nadciśnienia [17]. Stąd też postawiono hipotezę o częstym występowaniu nadwagi i otyłości $u$ chorych $\mathrm{z}$ nadciśnieniem. W badanej populacji $40 \%$ stanowią osoby z nadwagą, $20 \%$ chorzy z I stopniem otyłości i $10 \%$ pacjenci z II stopniem otyłości. W sumie aż 70\% ankietowanych ma podwyższony wskaźnik BMI, co potwierdza założoną hipotezę. 
W badaniu potwierdzono, że nadwaga i otyłość są nie tylko czynnikami ryzyka wystąpienia nadciśnienia, ale również wpływają na jakość życia. W dziedzinie fizycznej niższa jakość życia osób z nadwagą i otyłością w porównaniu z pacjentami z prawidłowym BMI jest widoczna szczególnie w odniesieniu do takich czynników jak: mobilność, wypoczynek i sen oraz zdolność do pracy. W dziedzinie psychologicznej badani $\mathrm{z}$ prawidłową wagą lepiej oceniają swój wygląd zewnętrzny, mają wyższą samoocenę oraz są bardziej zadowoleni ze swoich zdolności do koncentracji i uczenia się. W dziedzinie socjalnej istnieje niska korelacja jakości życia względem wskaźnika BMI, jednak chorzy z nadwagą i otyłością znacznie niżej oceniają swoją aktywność seksualną oraz nieznacznie niżej związki z partnerami. Również w dziedzinie socjalnej jakość życia oceniana jest lepiej przez osoby z niższym BMI, w szczególności w odniesieniu do środowiska domowego i transportu. Wyniki te wydają się potwierdzać doniosłość edukacji pacjentów w zakresie normalizacji masy ciała. Nadwaga i otyłość nie tylko sprzyjają rozwojowi nadciśnienia i jego powikłań, ale również wpływają na wszystkie aspekty życia chorego, obniżając jego jakość.

W literaturze przedmiotu możemy znaleźć liczne doniesienia na temat różnic w ocenie jakości życia ze względu na płeć pacjentów z nadciśnieniem tętniczym. W badaniach M. Stachowskiej i in. kobiety gorzej oceniły swój dobrostan w niemal wszystkich aspektach [18]. Natomiast B. Tobiasz-Adamczyk wskazuje, iż kobiety gorzej od mężczyzn radzą sobie zarówno z fizycznymi, jak i psychospołecznymi skutkami chorób układu krążenia [19]. Dowiedziono, że kobiety zgłaszają więcej problemów fizycznych i psychologicznych niż mężczyźni, co spowodowane jest często zaburzeniami snu i przeciążeniem obowiązkami domowymi, co przekłada się na niższą jakość życia [20].

Natomiast $\mathrm{z}$ przeprowadzonych badań wynika, iż nie występują istotne różnice pomiędzy oceną jakości życia i zadowolenia ze zdrowia pomiędzy kobietami, a mężczyznami. Biorąc pod uwagę 
samoocenę zdrowia kobiety uzyskały nieco wyższy wynik, natomiast średnie wyniki jakości życia są u obu płci tożsame. Jedynie dziedzina socjalna (związki osobiste, aktywność seksualna, wsparcie społeczne) została nieco lepiej oceniona przez mężczyzn. Jednak w żadnym aspekcie różnice nie są istotne statystycznie, co może wskazywać na zmiany w ocenie swojego życia przez kobiety na przestrzeni ostatnich lat i wymaga weryfikacji poprzez dalsze badania.

$\mathrm{W}$ analizie nie doszukano się istotnych różnic $\mathrm{w}$ odniesieniu do miejsca zamieszkania. Zarówno mieszkańcy wsi, jak i miasta pozytywnie ocenili jakość życia. W aspekcie fizycznym i socjalnym nieznacznie wyższą samoocenę mają osoby mieszkające $\mathrm{w}$ mieście, natomiast ze sfery psychologicznej i środowiskowej bardziej zadowoleni są pacjenci zamieszkujący obszary wiejskie. Do tych wyników należy odnosić się jednak z dużą ostrożnością, bowiem mieszkańcem wsi nie musi być osoba prowadząca gospodarstwo rolne. Z analiz demograficznych wynika, iż coraz większa grupa osób wyprowadza się z miasta do gmin podmiejskich, natomiast ich styl życia nie odbiega od osób mieszkających w zabudowie jednorodzinnej na przedmieściach. Zgodnie z danymi Urzędu Miasta Bydgoszczy od 2012 r. w mieście co roku ubywa ok. 2 tysięcy mieszkańców, przy prawie równoważnej ilości zgonów i narodzin [21].

Reasumując, w wyniku przeprowadzonych badań potwierdzono większość postawionych hipotez. Pacjenci z nadciśnieniem tętniczym oceniają jakość życia jako dobrą, nie są jednak zadowoleni ze swojego stanu zdrowia. Badani powyżej 60 . roku życia niżej niż inne grupy wiekowe oceniają swoje zadowolenie ze zdrowia oraz jakość życia, szczególnie w dziedzinach: fizycznej, psychologicznej i socjalnej. Jakość życia chorych z nadciśnieniem tętniczym jest silnie skorelowana $\mathrm{z}$ czasem trwania choroby oraz występowaniem innych schorzeń. Chorzy z nadciśnieniem tętniczym charakteryzują się podwyższonym wskaźnikiem BMI. Pacjenci z nadwagą i otyłością gorzej oceniają jakość życia od chorych z prawidłową masą ciała. Na jakość życia pacjentów nie mają 
natomiast wpływu zmienne takie społeczno-demograficzne, jak płeć i miejsce zamieszkania. Badania ujawniły także potrzebę edukacji pacjentów w zakresie niefarmakologicznych metod leczenia nadciśnienia.

\section{Wnioski}

1. Pacjenci z nadciśnieniem tętniczym oceniają jakość swojego życia jako dobrą. Natomiast stan zdrowia oceniają jako przeciętny.

2. Nie stwierdzono różnicy $\mathrm{w}$ jakości życia pacjentów z nadciśnieniem tętniczym ze względu na płeć.

3. Respondenci powyżej 60. roku życia wskazują na niższe zadowolenie ze zdrowia oraz jakości życia niż inne grupy wiekowe.

4. Mieszkańcy miasta i wsi nie wykazują istotnej różnicy w zakresie oceny jakości życia.

5. Osoby chorujące na nadciśnienie tętnicze powyżej 20 lat słabiej niż inne grupy oceniają jakość życia.

6. Pacjenci z nadciśnieniem tętniczym wykazują tendencję do występowania nadwagi. Pacjenci $\mathrm{z}$ nadwagą oraz otyłością niżej oceniają jakość życia od osób z prawidłowym BMI.

\section{Zalecenia dla praktyki pielęgniarskiej}

Wraz z rozwojem cywilizacji zwiększa się liczba pacjentów z nadciśnieniem tętniczym, jednocześnie wymusza to na personelu pielęgniarskim pogłębiania wiedzy na temat stylu życia i nawyków pacjentów. Czynniki ryzyka mają bezpośredni wpływ na przebieg oraz rozwój choroby, wprowadzoną terapię, ale także na stan psychiczny pacjenta. Wynikiem tego jest konieczność prowadzenia edukacji dla pacjenta i jego rodziny w kierunku zmiany stylu życia, co przekłada się na leczenie samej choroby, ale także podniesienie jakości życia pacjenta przy jej występowaniu. 


\section{Bibliografia/Bibliography:}

1. Muszalik M. Metody badania jakości życia związanej ze zdrowiem w: Pielęgniarstwo w opiece długoterminowej. Kornelia KędzioraKornatowska, M. Muszalik, E. Skolmowska (red.), Wydawnictwo Lekarskie PZWL, Warszawa 2010: 343-348.

2. Kearny P.M. Global burden of hypertension: analysis of worldwide data. Lancet. 2005; 365: 217-223.

3. Tykarski A., Grodzicki T. Zalecenia ESH / ESC 2007 dotyczące leczenia nadciśnienia tętniczego - co nowego? Próba komentarza na temat zmian i ich zasadności. Nadciśnienie tętnicze. Pismo P. T. N. T. 2007; XI (4): 261 - 303.

4. Januszewicz A. Nadciśnienie tętnicze - zarys patogenezy diagnostyki i leczenia. Wydawnictwo Medyczne Termedia, Poznań 2003: 87-95.

5. Hedner T., Kjeldsen S. E., Narkiewicz K. Nadciśnienie Tętnicze 2009, Wydanie 3. Wydawnictwo Medyczne Via Medica, Gdańsk 2009: 2-24.

6. Kawecka - Jaszcz K. i in. Rozpowszechnienie nadciśnienia tętniczego w zależności od płci w świetle badań epidemiologicznych w Polsce. Nadciśnienie Tętnicze 2007. 11 (5): 377 - 383.

7. Światowa Organizacja Zdrowia Study Protocol for the World Health Organization project to develop a Quality of Life assessment instrument (WHOQOL). Quality of Life Res., 1993, 2: 153-159.

8. Daszykowska J. Jakość życia w koncepcjach związanych ze zdrowiem. Przegląd Medyczny Uniwersytetu Rzeszowskiego. 2006; 2: 122-128.

9.Kowalik S. Pomiar jakości życia - kontrowersje teoretyczne. W: Pomiar i poczucie jakości życia u aktywnych zawodowo i bezrobotnych. Bańka A, Derbis R. (red.), UAM i WSP, Poznań-Częstochowa 1995.

10. Wojszel B. Uwarunkowania zdrowotne jakości życia oraz ocena stanu zdrowia ludzi starych. Gerontol. Pol. 1996, 4 (3): 28 - 34. 
11. Jopkiewicz A. Samoocena zdrowia, jakości życia i zaradności życiowej osób starszych. Rocznik Lubuski 2014, 40 (2): 261 - 273.

12. Muszalik M. Kędziora-Kornatowska K. Jakość życia przewlekle chorych pacjentów w starszym wieku. Gerontologia Polska 2006, 14 (4): 185 - 189.

13. Stachowska M. i in., Jakość życia pacjentów chorujących na nadciśnienie tętnicze. Hygeia Public Health 2014. 49 (4): 813 - 819.

14. Zygmuntowicz M., Chudek J., Olszanecka - Gilnianowicz M. Jakość życia osób z nadciśnieniem tętniczym. Endokrynologia, otyłość i zaburzenia przemiany materii 2011, 7 (3): 179 - 185.

15. Woźniacka i in. Ocena jakości życia pacjentów chorujących na nadciśnienie tętnicze według ankiety SF-36. Nadciśnienie Tętnicze 2008, 12 (2): $109-117$.

16. Januszewicz W., Sznajderman M., Nadciśnienie tętnicze. PZWL. Warszawa 1993: $150-151$

17. Widecka K., Grodzicki T., Narkiewicz K., Tykarski A., Dziwura J. Zasady postępowania w nadciśnieniu tętniczym - 2011 rok Wytyczne Polskiego Towarzystwa Nadciśnienia Tętniczego. Nadciśnienie Tętnicze, 2011; 15 (2): 211-235.

18. Stachowska M. i in., Jakość życia pacjentów chorujących na nadciśnienie tętnicze. Hygeia Public Health 2014. 49 (4): 813 - 819.

19. Kaplan M.N. Nadciśnienie tętnicze. Januszewicz A. (red). Lublin 2006: $138,200$.

20. Klocek M., Kawecka-Jaszcz K., Jakość życia osób z nadciśnieniem tętniczym. w: Jakość życia w chorobach układu sercowo-naczyniowego. Metody pomiaru i znaczenie kliniczne. Kawecka-Jaszcz K., Klocek M., Tobiasz-Adamczyk B. (red.) Wydawnictwo Medyczne Termedia, Poznań 2006: 119 - 149. 
21.Urząd Miasta Bydgoszczy. Bydgoszcz w liczbach. http://www.bydgoszcz.pl/miasto/statystyka/Bydgoszcz_w_liczbach.aspx 20 luty 2017. 